\title{
Pengujian Kesuksesan Implementasi Sistem Informasi Akuntansi Lembaga Keuangan Mikro: Modified Delone Mcleon Model
}

\author{
Riwayat Artikel: Diterima 3 okt 2015 Direvisi 1 Nov2015 Disetujui 3 Jan 2016
}

WAHYU MANUHARA PUTRA ${ }^{*} \&$ MUH. ALFIAN ${ }^{21}$

${ }^{1}$ Program Studi Akuntansi,Universitas Muhammadiyah Yogyakarta, Jl. Lingkar Selatan, Tamantirto, Kasihan, Bantul, D.I. Yogyakarta, 55183, Telp +274 387656, Indonesia.

${ }^{2}$ Pascasarjana Akuntansi Universitas Sebelas Maret, Jl. Ir. Sutami No. 36A, Surakarta, Jawa Tengah, 57126, Indonesia. *Corresponding Author, E_mail address: wahyu_mp45@yahoo.com

\begin{abstract}
This research is motivated by the importance of accounting software in the micro finance institutions led by UPK that has an important role as a catalyst for poverty alleviation. Various data dan field observations indicate that the financial system various LKM UPK has not shown the quality reliable dan relevant system performance, even accounting stdanards has not fully implemented. This study adapted the DeLone dan McLean model that has been modified McGill et al. (2003) to map dan design the essential components of a successful implementation of accounting software for individual users as well as analyzing various system variables on user satisfaction, dan the impact on individual performance. All hypotheses have been tested dan found to result impartial. This model will be the basis for making a prototype web-based accounting softaware that will be developed dan implemented in the second year. So the ultimate goal of this research is that microfinance institutions are able to be an instrument of poverty alleviation optimal sustainability.
\end{abstract}

Keywords: LKM; Accounting Software; DeLone;McLeon; Successful

\section{ABSTRAK}

Penelitian ini dilatarbelakangi oleh pentingnya software akuntansi di lembaga keuangan mikro yang dipimpin oleh UPK yang memiliki peran penting sebagai katalis untuk pengentasan kemiskinan. Berbagai data Dan observasi lapangan menunjukkan bahwa sistem keuangan berbagai LKM UPK belum menunjukkan kinerja sistem handal yang relevan Dan kualitas, bahkan akuntansi stdanards belum sepenuhnya dilaksanakan. Penelitian ini diadaptasi model DeLone Dan McLean yang telah dimodifikasi McGill et al. (2003) untuk memetakan Dan merancang komponen penting dari keberhasilan pelaksanaan software akuntansi untuk pengguna individu serta menganalisis berbagai variabel sistem pada kepuasan pengguna, Dan dampak pada kinerja individu. Semua hipotesis telah diuji Dan ditemukan hasil yang berimbang. Model ini akan menjadi dasar untuk membuat prototipe berbasis web softaware akuntansi yang akan dikembangkan Dan dilaksanakan pada tahun kedua. Jadi tujuan akhir dari penelitian ini adalah bahwa lembaga keuangan mikro dapat menjadi alat keberlanjutan optimal pengentasan kemiskinan.

Kata Kunci:LKM; Software Akuntansi; DeLone; McLone; Kesuksesan

\section{PENDAHULUAN}

Sistem software pada suatu organisasi yang sebelumnya dalam lingkungan manual telah mengalami perubahan dalam pola pemrosesan data. Perubahan tersebut juga berdampak pada pengguna akhir (end-user) selaku pihak yang mengoperasikan sistem software. Perubahan tersebut memerlukan adaptasi bagi pengguna terkait beragam fitur baru sistem software dan juga agar tidak menimbulkan culture shock. Kemungkinan dampak lain adalah berupa ketidaksesuaian dengan kebutuhan sistem informasi organisasi sehingga justru akan mengurangi kinerja pengguna.

Hubungan antara manusia sebagai pengguna sistem dan software akuntansi sebagai objek 
merupakan hubungan yang tidak terpisahkan. Pengguna merupakan penentu layak tidaknya suatu software digunakan. Jika pengguna merasa bahwa software tersebut tidak berkualitas dan tidak mampu memenuhi kebutuhan, maka software tersebut tidak layak digunakan. Sehingga pengguna akan mencari cara agar software tersebut diganti atau di up-grade menjadi software yang lebih efektif dan lebih efisien dibdaning dengan software yang lama.

Organisasi keuangan seperti Lembaga Keuangan Mikro juga menggunakan sistem yang didalamnya terdapat aplikasi software akuntansi. Software akuntansi pada LKM hanya terdapat di LKM pusat yang fungsinya mengontrol seluruh transaksi penerimaan simpanan dan pengeluaran kredit di seluruh cabang, sedangkan pada cabang terdapat software LKM yang terpisah-pisah untuk setiap bagian antara lain aplikasi (software) untuk operasional dan aplikasi kepegawaian. Software akuntansi yang terdapat di LKM pada masingmasing cabang berfungsi mengatur transaksi yang berasal dari nasabah baik berupa penerimaan simpanan dan untuk penyaluran kredit. Menyadari bahwa operasionalisasi suatu software akuntansi menyangkut aspek manusia sebagai pengguna akhir dan dampak perubahan yang disebabkannya, maka penting untuk memperhatikan keberadaan pengguna akhir dalam pemanfaatan software akuntansi (Istianingsih dan Wijanto 2008).

Pada organisasi LKM, sistem informasi yang didukung teknologi dapat memberikan nilai tambah bagi perusahaan jika didesain menjadi sistem informasi yang efektif. Namun demikian, pengukuran dan penilain kualitas suatu sistem informasi yang efektif sulit dilakukan secara langsung seperti pengukuran biaya-manfaat (Cahyo 2009). Kesulitan penelitian kesuksesan dan keefektifan sistem informasi secara langsung mendorong banyak peneliti mengembangkan model untuk menilai kesuksesan sistem informasi.
Model kesuksesan sistem informasi telah banyak dikembangkan oleh para peneliti (Bailey dan Person 1983, DeLone dan McLean 1992, Seddon 1997, Rai et al., 2002 dalam Sabherwal et al., 2004). Dilihat dari beberapa model kesuksesan sistem informasi tersebut, model DeLone dan McLean (1992) banyak mendapat perhatian dari para peneliti. DeLone dan McLean (1992) melakukan studi mengenai kesuksesan sistem informasi. Mereka menemukan bahwa kesuksesan sistem informasi dapat direpresentasikan oleh karakteristik kualitatif sistem (system quality), kualitas informasi (information quality), konsumsi terhadap output (use), respon pengguna terhadap sistem informasi (user satisfaction), pengaruh sistem informasi terhadap kebiasaan pengguna (individual impact), dan pengaruhnya terhadap kinerja organisasi (organizational impact).

Pada penelitian ini, Model DeLone dan McLean (1992) diadaptasikan dengan kondisi organisasi LKM sebagai objek penelitian. Adaptasi pada penelitian ini adalah sofware akuntansi organisasi LKM berbasis modifikasian McGill et al. (2003) serta berfokus pada pengaruh variabel-variabel eksogen ke variabel dampak kinerja individu. Alasanya adalah karena penelitian ini difokuskan pada pendapat dari pengguna software akuntansi LKM terhadap aplikasi yang ada pada organisasi LKM dimana pengguna tersebut bekerja dan bagaimana pengaruh atau dampak yang ditimbulkan dari penggunaan software akuntansi tersebut terhadap peningkatan kinerja pengguna.

Model DeLone dan McLean (1992) yang dimodifiaksi McGill et al. (2003) menyatakan bahwa sistem informasi sukses jika kualitas sistem berpengaruh terhadap persepsi kualitas sistem. Setelah timbul persepsi kualitas sistem, maka persepsi ini akan berpengaruh terhadap penggunaan dan kepuasan pengguna akhir sistem. Pada kualitas informasi yang dihasilkan sistem juga 
dapat memengaruhi intensitas penggunaan dan kepuasan pengguna akhir sistem (pengguna software akuntansi LKM). Setelah itu dilihat, dari intensitas penggunaan dan kepuasan pengguna akhir apakah memengaruhi kinerja individual atau tidak. Jika memengaruhi maka dilakukan pengujian untuk melihat kinerja individual berpengaruh kepada kinerja organisasi atau tidak.

Mengacu pada hasil penelitian yang berkaitan dengan kesusksesan pengukuran sistem, maka penelitian ini diharapkan memberikan kontribusi sebagai berikut: (1) Membangun Model Perancangan kualitas sistem pada Lembaga Keuangan Mikro; (2) Membangun Model Perancangan kepuasan pengguna akhir pada Lembaga Keuangan Mikro; (3) Membangun Model Perancangan dampak individual pada Lembaga Keuangan Mikro; (4) Menganalisis Keterkaitan kualitas sistem, kepuasan pengguna dan dampak individual pada Lembaga Keuangan Mikro mendasarkan DeLone dan McLean Model Modifikasian; (5) Membangun Web terkait kualitas sistem, kepuasan pengguna dan dampak individual.

\section{TINJAUAN LITERATUR DAN PERUMUSAN HIPOTESIS \\ SOFTWARE AKUNTANSI}

Software akuntansi bermakna serang-kaian program komputer yang tersedia secara komersial dan berfungsi memberikan instruksi kepada komputer untuk melakukan pemrosesan data, dalam hal ini, untuk melakukan pengolahan datadata akuntansi (Rama dan Jones, 2006; Romney dan Steinbart, 2006; Turban, et al., 2006 dalam Radityo dan Zulaikha 2007). Software Akuntansi juga bisa didefinisikan sebagai perangkat lunak (software) yang dibuat untuk memudahkan aktivitas dan pencatatan akuntansi dengan memanfaatkan konsep modularitas atas serangkaian aktivitas yang serupa ke dalam modul-modul spesifik seperti pembelian (Accountant payable), penjualan (Accountan receivable), penggajian, buku besar, dan lain-lain. Perangkat lunak ini bisa merupakan perangkat lunak yang dikembangkan sendiri oleh perusahaan, atau dibeli dari pihak ketiga yang menye-diakannya, atau dapat pula merupakan kombinasi dari keduanya. Karena hal tersebut, kompleksitas dan kapabilitas perangkat lunak akuntansi menjadi sangat beragam bergantung pada kondisi lingkungan perusahaan yang akan menggunakannya.

\section{MODEL KEBERHASILAN SISTEM INFORMASI DELONE DAN MCLEAN}

Sukses atau tidaknya suatu Sistem Teknologi Informasi dalam organisasi tergantung beberapa faktor. Berdasarkan teori-teori dan hasil-hasil penelitian, DeLone dan McLean (1992) mengembangkan suatu model yang dinamakan model kesuksesan DeLone dan McLean (DdanM IS Success Model) sebagai berikut ini.

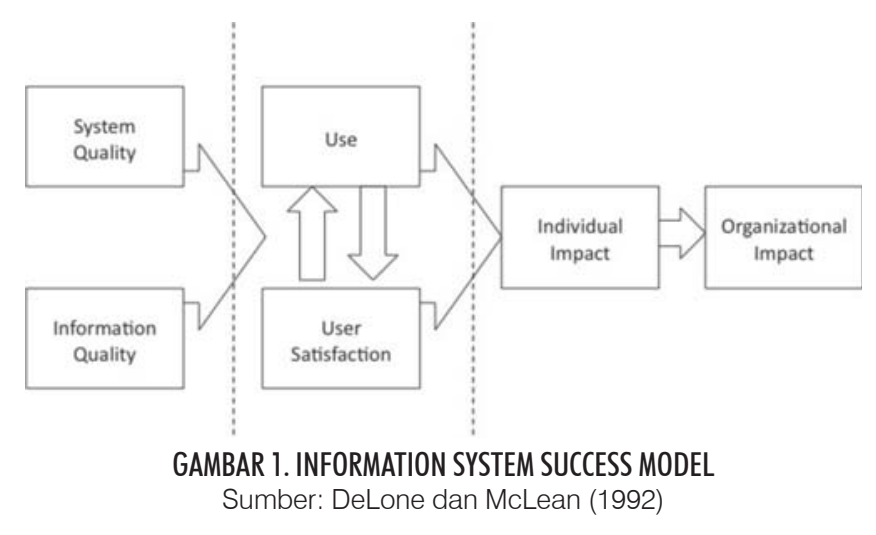

Model pada Gambar 1 merefleksikan ketergantungan enam pengukuran kesuksesan sistem informasi termasuk e-government yaitu: kualitas sistem (system quality), kualitas informasi (information quality), penggunaan (use), kepuasan pemakai (user satidfaction), Dampak Individu (individual impact), dampak organisasi (organization 
impact). Argumentasinya adalah suatu sistem terdiri dari beberapa proses, yaitu satu proses mengikuti proses yang lainnya, maka kualitas sistem dan kualitas informasi secara mdaniri dan bersamasama mempengaruhi peng-gunaan dan kepuasan pemakai. Besarnya penggunaan dapat mempengaruhi kepuasan pemakai secara positif atau negatif. Penggunaan dan kepuasan pemakai mempe-ngaruhi dampak individual dan selanjutnya mempengaruhi dampak organisasional. Model kesuksesan sistem informasi DdanM (DdanM Information System Success Model) dipicu proses pembuatan informasi dan dampak penggunaan sistem informasinya, yaitu pembuatan dari suatu sistem informasi, penggunaan sistem informasi tersebut, dan konsekuensi atau dampak dari penggunaan sistem Menurut Edberg dan Bowman (1996) dan McGill et al., 2003) system quality yang ada dalam Model IS Success DeLone dan McLean mengdanung unsur subjektif dan objektif. Ukuran system quality DeLone dan McLean adalah kemudahan dalam penggunaan, fungsional, reliabilitas, fleksi-bilitas, kualitas data, adanya kemungkinan-kemungkinan, integrasi dan kepentingan. Seddon dan Kiew (1996) melakukan pengujian atas pengaruh variabel system quality terhadap user satisfaction. Hasilnya konsisten dengan hasil pengujian DeLone dan McLean (1992).

Penelitian lain yang melakukan pengujian terhadap hubungan dua variabel ini yaitu Roldan dan Millan (2000) dan Rivard et al. (1997) mendukung adanya hubungan dari dua variabel ini.

Menurut DeLone dan McLean (1992) information quality diukur dengan faktor keakuratan, kecepatan, kelengkapan, relevan dan konsisten. Hubungan variabel information quality terhadap user satisfaction juga diteliti oleh Seddon dan Kiew (1996) yang mendukung adanya hubungan antara information quality dan user satisfaction. Rollan dan Millan (2000) juga mendukung adanya pengaruh dari information quality terhadap user satisfaction.

McGill et al. (2003) membuat dua perubahan pada model DeLone dan McLean, perubahan pertama yaitu konstruk kualitas sistem dipecah menjadi dua yaitu, variabel Kualitas Sistem (KS) dan Persepesi Kualitas Sistem (PKS). Perubahan kedua yaitu, menghilangkan arah anak panah dari Penggunaan Sistem (PS) terhadap Kepuasan Pengguna Akhir (KPA). Modifikasian McGill et al. (2003) untuk menguji konsistensi model kesuksesan sistem informasi DeLone dan McLean dapat dilihat dari Gambar 2.

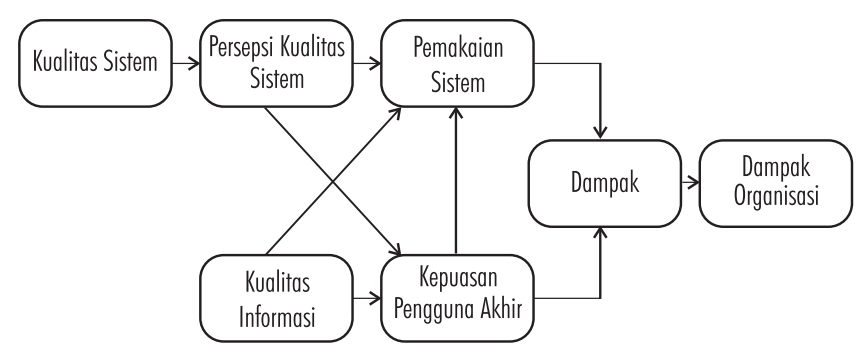

GAMBAR 2. MODEL KESUKSESAN SISTEM INFORMASI MODEL DELONE DAN MCLEAN YANG DIMODIFIKASI MCGILL ETAL (2003) Sumber: McGill, Hobbs, dan klobas (2003)

Model DeLone dan McLean yang dimodifikasi McGill et al. (2003) diatas menunjukkan hubungan sebab akibat bahwa Kualitas Sistem (KS) berpengaruh positif terhadap Persepsi Kualitas Sistem (PKS). Kualitas Informasi (KI) dan Persepsi Kualitas Sistem (PKS) berpengaruh positif terhadap Kepuasan Pengguna Akhir (KPA). Kualitas Informasi (KI) dan Persepsi Kualitas Sistem (PKS) berpengaruh positif terhadap pemakaian Sistem (PS). Pemakaian Sistem (PS) dan Kepuasan Pengguna Akhir (KPA) berpengaruh secara positif terhadap Dampak Individual (DI), dan Dampak Individual (DI) berpengaruh terhadap Dampak Organisasi (DO).

\section{HASIL DAN PEMBAHASAN}

KUALITAS SISTEM DAN PERSEPSI KUALITAS SISTEM 
Kualitas sistem merupakan karakteristik dari informasi yang melekat mengenai sistem itu sendiri DeLone dan McLean (1992). Kualitas sistem juga didefinisikan sebagai perceived ease of use yang merupakan seberapa besar teknologi komputer dirasakan relatif mudah untuk dipahami dan digunakan. Sedangkan persepsi kualitas sistem di sini adalah persepsi pengguna akan dampak dari penggunaan software akuntansi terhadap peningkatan kinerja dari para pengguna akhir (Davis et al., 1989; Chin dan Todd (1995) dalam Istianingsih dan Wijanto (2008). Penekanan atas aspek kualitas sistem di dalam suatu pengimplementasian software akuntansi, akan meningkatkan antusiasme penggunanya, yang tercermin lewat meningkatnya nilai persepsi atas kualitas sistem, sehingga pada akhirnya memberikan kontribusi terhadap keberhasilan imple-mentasi dari software akuntansi. Menurut penjelasan tersebut dapat ditarik suatu hipotesis, yaitu:

$H_{1}$ : Kualitas sistem memiliki pengaruh positif terhadap persepsi kualitas sistem.

\section{PERSEPSI KUALITAS SISTEM DAN KEPUASAN PENGGUNA AKHIR}

Peter B Seddon (1997) mengemukakan bahwa persepsi kualitas sistem secara signifikan mempengaruhi kepuasan pengguna akhir. Jika pengguna software akuntansi telah mempunyai persepsi terhadap kualitas sistem serta yakin dengan kualitas sistem yang digunakannya, dan merasakan bahwa menggunakan sistem tersebut tidak sulit, maka mereka akan percaya bahwa penggunaan sistem tersebut akan memberikan manfaat yang lebih besar dan akan meningkatkan kinerja mereka. Jika informasi yang dihasilkan dari software akuntansi yang digunakan semakin akurat, tepat waktu, dan memiliki reliabilitas yang baik, maka akan semakin meningkatkan kepercayaan pemakai sistem tersebut. Peningkatan kepercayaan pemakai sistem informasi, diharapkan akan semakin meningkatkan kinerja mereka. Sedangkan ukuran kepuasan pemakai pada sistem komputer dicerminkan oleh kualitas sistem yang dimiliki, kepuasan pemakai terhadap suatu sistem informasi adalah bagaimana cara pemakai memdanang sistem informasi secara nyata, bukan pada kualitas sistem secara teknik. Penelitian McGill (2003) menyatakan bahwa perceived system quality memiliki hubungan positif signifikan terhadap user satisfaction. Dita (2011) juga menyatakan bahwa persepsi kualitas sistem memiliki pengaruh positif terhadap kepuasan pengguna. Penelitian Widananto (2008) juga menemukan hasil bahwa persepsi kualitas sistem berpengaruh positif terhadap kepuasan pengguna. Terakhir adalah penelitian Cahyo dan Kurniawan (2010) bahwa persepsi kualitas sistem mempunyai pengaruh positif terhadap kepuasan pengguna akhir. Dari penjelasan tersebut dapat ditarik suatu hipotesis, yaitu:

$\mathrm{H}_{2}$ : Persepsi kualitas sistem memiliki pengaruh positif terhadap kepuasan pengguna akhir.

\section{KUALITAS INFORMASI DAN KEPUASAN PENGGUNA AKHIR}

Kualitas informasi merupakan output yang berupa informasi yang dihasilkan oleh sistem informasi yang digunakan, Rei et al. dalam Istianingsih dan Setyo (2008). Semakin tinggi kualitas informasi yang dihasilkan suatu sistem informasi, akan semakin meningkatkan kepuasan pemakai (DeLone dan McLean, 1992). Jika pemakai sistem informasi percaya bahwa kualitas sistem dan kualitas informasi yang dihasilkan dari sistem yang digunakan adalah baik, mereka akan merasa puas menggunakan sistem tersebut. Seddon dan Kiew dalam Istianingsih dan Wiwik (2009) telah melakukan pengujian mengenai pengaruh dari kualitas informasi terhadap kepuasan 
pengguna akhir sistem informasi. Hasil pengujian mereka menunjukkan bahwa kualitas informasi berhubungan positif dengan kepuasan pengguna akhir sistem informasi. Dari penjelasan tersebut dapat ditarik suatu hipotesis, yaitu:

$\mathrm{H}_{3}$ : Kualitas Informasi memiliki pengaruh positif terhadap kepuasan pengguna akhir.

\section{KEPUASAN PENGGUNA AKHIR DAN PENGGUNAAN SISTEM}

Kepuasan pengguna (user satisfaction) merupakan respon dan umpan balik pemakai terhadap penggunaan keluaran software akuntansi. Sikap pemakai terhadap software akuntansi merupakan kriteria subyektif mengenai seberapa suka pemakai terhadap software akuntansi yang digunakannya. Variabel ini diukur dari Chin et al. (1998) semakin tinggi tingkat kepuasan pengguna, maka semakin tinggi penggunaan system (lihat juga: Jogiyanto, 2000). Kartana (2008) dalam penelitiannya menujukkan bahwa kepuasan dan penggunaan sistem saling berhubungan timbal balik. Imam (2009) dalam penelitiannya menyatakan bahwa kepuasan pengguna dan penggunaan sistem saling berhubungan timbal balik.

Hasil penelitian Sumiyana dan Angelina (2010) terhadap kepuasan pengguna dan penggunaan sistem menunjukkan pengaruh positif dimana kedua variabel ini berpengaruh terhadap peningkatan kinerja. Cahyo dan Kurniawan (2010) mengemukakan dalam penelitiannya bahwa kepuasan pengguna akhir secara signifikan mempengaruhi penggunaan sistem. Penggunaan sistem informasi yang telah dikembangkan mengacu pada seberapa sering pengguna memakai sistem informasi. Semakin sering pengguna memakai sistem informasi, biasanya diikuti oleh semakin banyak tingkat pembelajaran (degree of learning) yang didapat pengguna mengenai sistem informasi. Dari penjelasan tersebut dapat ditarik suatu hipotesis, yaitu:

$\mathrm{H}_{4}$ : Kepuasan pengguna akhir memiliki pengaruh positif terhadap penggu-naan sistem.

\section{KUALITAS INFORMASI DAN PENGGUNAAN SISTEM}

Kualitas informasi merupakan persepsi dari para pengguna tentang seberapa bisakah suatu software akuntansi itu mampu menunjukkan dan menyampaikan pesan yang dimaksud, kualitas informasi merupakan output yang dihasilkan oleh sistem informasi yang digunakan (DeLone dan McLean, 1992), atau bisa juga dikatakan output dari software tersebut. Kualitas dari suatu informasi (quality of information) tergantung dari tiga hal, yaitu informasi harus akurat (accurate), tepat pada waktunya (timely basis), dan relevan (relevance). Akurat apabila Informasi tersebut bebas dari kesalahan-kesalahan dan tidak bias atau menyesatkan. Akurat juga berarti informasi harus jelas mencerminkan maksudnya. Informasi harus akurat karena dari sumber informasi sampai ke penerima informasi kemungkinan banyak terjadi gangguan (noise) yang dapat merubah atau merusak informasi tersebut. Tepat pada waktunya jika Informasi yang datang pada penerima tidak terlambat, informasi yang sudah usang tidak akan mempunyai nilai lagi, karena informasi merupakan ldanasan didalam pengambilan keputusan.

Bila pengambilan keputusan terlambat, maka dapat berakibat fatal untuk organisasi. Sedangkan relevan apabila Informasi tersebut mempunyai manfaat untuk pemakainya. Relevansi informasi untuk tiap-tiap orang satu dengan yang lainnya berbeda. Sehingga jika kualitas informasi pada suatu software akuntansi sangat bagus maka akan semakin bisa menarik pengguna untuk menggunakan sistem tersebut, penggunaan sistem disini sangat tergantung dengan kualitas suatu sistem itu sendiri. Jika pemakai sistem informasi percaya bahwa kualitas sistem dan kualitas 
informasi yang dihasilkan dari sistem yang digunakan adalah baik, mereka akan sering menggunakan sistem tersebut. Dari penjelasan tersebut dapat ditarik suatu hipotesis, yaitu:

$H_{5}$ : Kualitas informasi memiliki pengaruh positif terhadap penggunaan sistem.

\section{PERSEPSI KUALITAS SISTEM DAN PENGGUNAAN SISTEM}

Persepsi kualitas sistem terkait dengan para pengguna akhir yaitu sehubungan dengan persepsi mereka tentang sistem dan juga kualitasnya dari suatu software akuntansi tersebut, sehingga jika pengguna memiliki persepsi yang baik terhadap suatu software akuntansi maka mereka akan menggunakan software akuntansi tersebut. Jika mereka merasa terbantu dan merasa bahwa kinerjanya semakin meningkat dengan adanya sistem tersebut maka para pengguna pasti akan sering menggunakan software akuntansi tersebut, sehingga disini jelas terlihat bahwa penggunaan sistem tergantung dengan persepsi para pengguna akhir terhadap sistem tersebut. Dari penjelasan tersebut dapat ditarik suatu hipotesis, yaitu:

$\mathrm{H}_{6}$ : Persepsi kualitas sistem memiliki pengaruh positif terhadap penggunaan sistem.

\section{KEPUASAN PENGGUNA AKHIR DAN DAMPAK INDIVIDUAL}

Ukuran kepuasan pemakai pada sistem komputer dicerminkan oleh kualitas sistem yang dimiliki (Guimaraes, Igbaria, dan Lu 1992; Yoon, Guimaraes, dan O’Neal, 1995; Sumiyana 2006). Kepuasan pemakai terhadap suatu sistem informasi adalah bagaimana cara pemakai memdanang sistem informasi secara nyata, bukan pada kualitas sistem secara teknik (Guimaraes, Staples, dan McKeen, 2003; Wijanto, 2008). Dalam literatur penelitian maupun dalam praktek, kepuasan pengguna seringkali digunakan sebagai ukuran pengganti dari efektivitas sistem informasi (Melone, 1990; Cahyo dan Kurniawan 2010). Semakin sering pengguna memakai sistem informasi, biasanya diikuti oleh semakin banyak tingkat pembelajaran (degree of learning) yang didapat pengguna mengenai sistem informasi (McGill et al., 2005; Radityo dan Zulaikha, 2007).

Peningkatan derajat pembelajaran ini merupakan salah satu indikator bahwa terdapat pengaruh kebe-radaan sistem terhadap dampak individual (individual impact). Jadi dampak individu disini dimaksudkan dengan dampak dari software akuntansi terhadap perilaku dan kinerja penggunanya. Oleh karena itu tingkat kepuasan pengguna akhir sangat terlihat dari dampak individualnya, semakin baik kinerja pengguna maka mengindikasikan semakin puas pula para pengguna terhadap software akuntansi yang telah digunakan. Hal ini tidak sejalan dengan penelitian Radityo dan Zulaikha (2007) yang mana tidak menemukan adanya pengaruh antara kepuasan pengguna dengan damapak individual, lebih lanjut diungkapkan bahwa subyek penelitian lebih bersifat mdanatory. Dari penjelasan tersebut dapat ditarik suatu hipotesis, yaitu:

$H_{7}$ : Kepuasan pengguna akhir memiliki pengaruh positif terhadap dampak individual.

\section{PENGGUNAAN SISTEM DAN DAMPAK INDIVIDUAL}

Penggunaan sistem informasi yang telah dikembangkan mengacu pada seberapa sering pengguna memakai sistem informasi. Semakin sering pengguna memakai sistem informasi, biasanya diikuti oleh semakin banyak tingkat pembelajaran (degree of learning) yang didapat pengguna mengenai sistem informasi (McGill et al., 2005; Radityo dan Zulaikha, 2007). Peningkatan derajat pembelajaran ini merupakan salah satu indikator bahwa terdapat pengaruh keberadaan sistem terhadap kualitas pengguna (individual 
impact). Namun, Livary (2005) memberikan bukti empiris bahwa kualitas sistem dan kualitas informasi tidak berpengaruh signifikan terhadap intensitas penggunaannya, dan berpengaruh signifikan terhadap kepuasan penggunanya. Hal ini dikarenakan obyek penelitian Livary (2005) menggunakan obyek penggunaan sistem yang mdanatory. Selanjutnya kepuasan pengguna tersebut berpengaruh terhadap individual impact. Individual impact atau dampak individual merupakan pengaruh dari keberadaan dan pemakaian sistem informasi terhadap kinerja, pengambilan keputusan, dan derajat pembelajaran individu dalam organisasi.

Leavit (1965) mencermati bahwa penerapan sistem informasi yang baru akan berdampak pada reaksi yang ditunjukkan oleh perilaku individu dalam organisasi (lihat juga: Radityo dan Zulaikha, 2007). Reaksi itu dapat berupa munculnya motivasi baru untuk bersaing dan meningkatkan kinerja. Secara positif keberadaan sistem informasi baru akan menjadi rangsangan (stimulus) dan tantangan bagi individu dalam organisasi untuk bekerja secara lebih baik, yang pada gilirannya berdampak pada kinerja organisasi. Dari penjelasan tersebut dapat ditarik suatu hipotesis, yaitu:

$\mathrm{H}_{8}$ : Penggunaan sistem memiliki pengaruh positif terhadap dampak individual

\section{METODE PENELITIAN OBYEK PENELITIAN}

Obyek penelitian ini adalah lembaga keuangan mikro PNPM UPK di Bantul, yang menggunakan software akuntansi. Subyek penelitian adalah para karyawan lembaga tersebut. Metode penelitian menggunakan survei dengan data primer melalui kuesiner. Definisi operasional seluruh variabel dalam penelitian ini bersumber dari McGill et al. (2003) dengan 5 skala Likert dari sangat tidak setuju sampai sangat setuju. Metode pengujian statistik menggunakan Partial Least Square (PLS). PLS dapat digunakan pada setiap jenis skala data (nominal, ordinal, interval, rasio) serta syarat asumsi yang lebih fleksibel. PLS juga digunakan untuk mengukur hubungan setiap indikator dengan konstruknya. Selain itu, dalam PLS dapat dilakukan uji bootstrapping terhadap struktural model yang bersifat outer model dan inner model.

\section{HASIL DAN PEMBAHASAN GAMBARAN OBJEK PENELITIAN}

Subyek penelitian adalah pengurus UPK yang terdiri ketua, sekretaris dan bendahara. Penelitian ini menggunakan 17 UPK di Kabupaten Bantul. Hasil penyebaran kuesioner sebanyak 51 kuesioner berhasil terkumpul sebanyak 45 kuesioner. Kuesioner yang kembali dan layak digunakan untuk analisis lebih lanjut sebanyak 45 kuesioner.

TABEL I. SAMPEL DAN TINGKAT PENGEMBALIAN KUISIONER

\begin{tabular}{ll}
\hline Keterangan & Jumlah \\
\hline Kuesioner yang disebar & 51 \\
Kuesioner yang tidak kembali & 6 \\
Kuesioner yang kembali & 45 \\
Kuesioner yang tidak diisi secara lengkap & 0 \\
Kuesioner yang dapat diolah & 45 \\
Tingkat pengembalian & $88 \%$ \\
\hline
\end{tabular}

\section{MERANCANG MODEL PENGUKURAN (OUTER MODEL)}

Tahap ini untuk mengetahui validitas dan reliabilitas yang menghubungkan indikator dengan variabel latennya. Indikator penelitian ini adalah reflektif karena indikator variabel laten mempengaruhi indikatornya untuk itu digunakan tiga tahap pengukuran yaitu:

\section{DISCRIMINANT VALIDITY}

Evaluasi dilakukan untuk melihat square root of average variance extracted (AVE). Model pengukuran dinilai berdasarkan pengukuran cross loading dengan 
konstruk. Jika kolerasi konstruk dengan setiap indikatornya lebih besar daripada ukuran konstruk lainnya, maka konstruk laten memprediksi indikatornya lebih baik daripada konstruk lainnya. Jika nilai $\sqrt{A V E}$ lebih tinggi daripada nilai kolerasi di antara konstruk, maka discriminant validity yang baik tercapai. Menurut Latan dan Ghozali 2012 sangat direkomendasikan apabila AVE lebih besar dari 0,5. Berdasarkan hasil olah data yang dilakukan dengan bantuan software SmartPLS 2.0 didapatkan bahwa nilai AVE untuk semua konstruk $>0,50$. Sehingga dapat memenuhi syarat validitas konvergen.

\section{COMPOSITE RELIABILITY}

Untuk menentukan composite reliability, apabila nilai composite reliability $\rho c>0,8$ dapat dikatakan bahwa konstruk memiliki reliabilitas yang tinggi atau reliable dan $\rho c>0,6$ dikatakan cukup reliable (Chin 1998). Berdasarkan hasil olah data SmartPLS 2.0 didapatkan bahwa nilai Composite Reliability untuk semua konstruk > 0,70.

Sehingga dapat disimpulkan bahwa semua indikator konstruk adalah reliable atau dengan kata lain memenuhi uji reliabilitas.

\section{CRONBACH ALPHA}

Uji reliabilitas diperkuat dengan adanya cronbach alpha dimana konsistensi setiap jawaban diujikan. Cronbach alpha baik apabila $\alpha \geq 0,5$ dan dikatakan cukup apabila 0,3. Nilai cronbach alpha yang dihasilkan semua konstruk sangat baik yaitu > 0,7 sehingga dapat disimpulkan bahwa semua indikator konstruk reflektif adalah reliable atau memenuhi uji reliabilitas. Namun demikian menurut Latan dan Ghozali (2012) cronbach alpha yang dihasilkan sedikit under estimate sehingga disarankan untuk menggunakan Composite Reliability atau DillionGoldstein's.

\section{MERANCANG MODEL STRUKTURAL (INNER MODEL)}

Model struktural menggunakan R-square untuk konstruk dependen, Stone-Geisser Q-square test untuk predictive relevane dan uji t serta signifikan dari koefisien parameter jalur struktural. $R^{2}$ digunakan untuk menilai pengaruh variabel laten independen terhadap variabel laten dependen. Kriteria batasan nilai $R^{2}$ ini dalam tiga klasifikasi, yaitu 0,67, 0,33, dan 0,19. Disamping itu juga melihat Qsquare predictive relevance untuk mengukur sebeapa baik nilai observasi dan juga estimasi parameternya. Nilai Q-square lebih besar dari 0 menunjukan bahwa model mempunyai nilai predictive relevance, sedangkan nilai Q-square kurang dari 0 menunjukan bahwa model kurang memiliki predictive relevance.

Diketahui bahwa nilai R-Square Dampak Individu (DI) 0,613254 atau 61,32\%, hal tersebut menunjukan bahwa Pemakaian Sistem (PS) dan Kepuasan Pengguna Akhir (KPA) berpengaruh terhadap DI sebesar 61,32\% sehingga dimungkinkan 38,68\% DI dipengaruhi oleh variabel lain. Nilai $R$-Square dari variabel KPA sebesar 33,91\%, menunjukan bahwa Persepsi Kualitas Sistem (PKS) dan Kualitas Informasi (KI) mempengaruhi KPA sebesar 33,91\% sehingga terdapat $66,09 \%$ variabel lain yang mempengaruhi KPA.

Nilai R-Square variabel PKS 20,78\%, menunjukan bahwa PKS dipengaruhi oleh Kualitas Sistem sebesar 20,78\% sehingga masih terdapat $79,22 \%$ variabel lain yang mempengaruhi PKS. Nilai R-Square variabel PS 35,57\%, menunjukan bahwa variabel PS dipengaruhi oleh PKS, KI dan KPA sebesar 35,57\% sehingga masih terdapat 64,43 $\%$ variabel lain yang mempengaruhi PS.

\section{UJ HIPOTESIS (RESAMPLING BOOTSTRAPING)}

Tingkat kepercayaan yang digunakan 95\%, sehingga tingkat presisi sebesar ()$=5 \%=0,05$, dan 


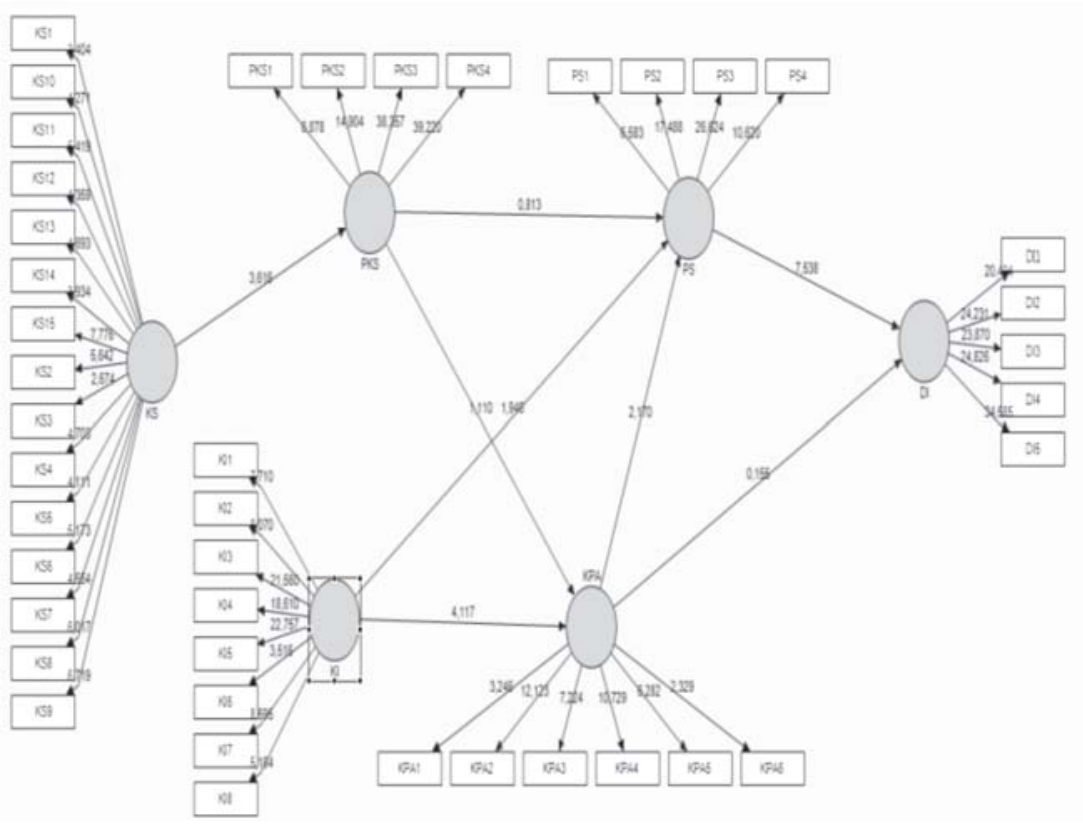

GAMBAR 3. KONSTRUKSI DIAGRAM JALUR PENELITIAN

nilai t-tabel 1.98 (Latan dan Ghozali, 2012). Jika nilai t-statistik lebih kecil dari nilai t-tabel, maka $H_{o}$ diterima dan $H_{a}$ ditolak. Sedangkan jika nilai tstatistik lebih besar, maka $\mathrm{H}_{o}$ ditolak dan $\mathrm{H}_{a}$ diterima.Parameter estimasi antara kualitas sistem (KS) dengan persepsi kualitas sistem software (PKS) menghasilkan nilai t-statistics 3,615730. Nilai tstatistics ini lebih besar daripada nilai kritis 1,98 dengan tingkat signifikansi 5\%, maka $\mathrm{H}_{1}$ diterima. Nilai t pada persepsi kualitas sistem (PKS) dengan kepuasan pengguna akhir (KPA) sebesar 1,109844, lebih kecil daripada 1,98 maka H2 ditolak. Nilai t kualitas informasi (KI) dengan kepuasan pengguna akhir (KPA) sebesar 4,117445 yang lebih besar daripada 1,98 sehingga H3 diterima. Nilai $t$ 2,170369 diperoleh pada pestimasi kepuasan pengguna akhir (KPA) dengan penggunaan sistem (PS), karena lebih besar daripada nilai kritis, maka $\mathrm{H}_{4}$ diterima.

Parameter estimasi kualitas informasi (KI) dengan penggunaan sistem (PS) menghasilkan nilai t 1,945810, lebih kecil daripada 1,98 dengan á 5\%, maka H4 ditolak. Estimasi persepsi kualitas sistem
(PKS) dengan penggunaan sistem (PS) memiliki nilai t 0,812601 , lebih kecil daripada 1,98 maka H6 ditolak. Nilai t 0,154632 diperoleh pada kepuasan pengguna akhir (KPA) dengan dampak individual (DI) lebih kecil daripada 1,98, sehingga $\mathrm{H}_{7}$ ditolak. Nilai $t 7,537686$ yang dihasilkan pada estimasi penggunaan sistem (PS) dengan dampak individual lebih besar daripada 1,98 sehingga $\mathrm{H}_{8}$ diterima.

\section{DISKUSI}

Hipotesis pertama membuktikan bahwa kualitas sistem berpengaruh positif terhadap persepsi kualitas sistem. Penekanan atas aspek kualitas sistem di dalam suatu pengimplementasian software akuntansi akan meningkatkan antusiasme penggunanya, yang tercermin lewat meningkatnya nilai persepsi kualitas sistem, sehingga pada akhirnya memberikan kontribusi terhadap keberhasilan implementasi dari software akuntansi. Hasil pengujian terhadap $\mathrm{H}_{1}$ sesuai dengan penelitian Kurniawan dan Cahyo (2010) yang menyimpulkan bahwa kualitas sistem mempunyai pengaruh yang positif terhadap persepsi kualitas 
TABEL 2. HASIL PENGUJIAN HIPOTESIS

\begin{tabular}{llll}
\hline & Arah & T-Statistics & Simpulan \\
& Hipotesis & & \\
\hline KI - > KPA & + & 4,12 & Diterima \\
KI - > PS & + & 1,95 & Ditolak \\
KPA - > DI & + & 0,15 & Ditolak \\
KPA -> PS & + & 2,17 & Diterima \\
KS - > PKS & + & 3,61 & Diterima \\
PKS - > KPA & + & 1,10 & Ditoak \\
PKS -> PS & + & 0,81 & Ditolak \\
PS - > DI & + & 7,54 & Diterima \\
\hline
\end{tabular}

sistem. Hasil Pengujian Septi (2011) juga menunjukkan hasil yang sama bahwa kualitas sistem memiliki pengaruh positif terhadap persepsi kualitas sistem.

Pengujian $\mathrm{H}_{2}$ menunjukkan bahwa persepsi kualitas system tidak berpengaruh positif terhadap kepuasan pengguna akhir. Jika pengguna software akuntansi telah mempunyai persepsi terhadap kualitas sistem serta yakin dengan kualitas sistem yang digunakannya, dan merasakan bahwa menggunakan sistem tersebut tidak sulit, namun mereka tidak akan langsung percaya bahwa penggunaan sistem tersebut akan memberikan manfaat yang lebih besar dan akan meningkatkan kinerja mereka. Jika informasi yang dihasilkan dari software akuntansi yang digunakan semakin akurat, tepat waktu dan memiliki reliabilitas yang baik, maka akan tidak selalu meningkatkan kepercayaan pemakai sistem tersebut. Peningkatan kepercayaan pemakai sistem informasi, diharapkan akan semakin meningkatkan kinerja sehingga kepuasan pengguna juga akan meningkat.

Pengujian $\mathrm{H}_{2}$ tidak sejalan dengan penelitian Kurniawan dan Cahyo (2010) yang menyimpulkan bahwa persepsi kualitas sistem mempunyai pengaruh positif terhadap kepuasan pengguna akhir. Penelitian Widananto (2008) juga menemukan hasil yang sama bahwa persepsi kualitas sistem berpengaruh positif terhadap kepuasan pengguna

Hipotesis ketiga membuktikan bahwa kualitas informasi berpengaruh positif terhadap kepuasan pengguna akhir. Kualitas informasi merupakan output yang berupa informasi yang dihasilkan oleh sistem informasi yang digunakan. Semakin lengkap informasi yang tersedia, maka akan semakin tinggi pula tingkat kepuasan pengguna terhadap sistem secara keseluruhan. Hasil Pengujian ini sesuai dengan penelitian Kurniawan dan Cahyo (2010) yang menyim-pulkan bahwa kualitas sistem informasi mempunyai pengaruh positif terhadap kepuasan pengguna akhir. Pengujian Istianingsih dan Wiwik (2009), Istianingsih dan Setyo (2008) dalam penelitiannya juga menemukan hubungan yang positif signifikan antara kualitas informasi dengan kepuasan pengguna akhir.

Pengujian $\mathrm{H}_{4}$ menyimpulkan bahwa kepuasan pengguna akhir berpengaruh positif terhadap penggunaan sistem. Kepuasan pengguna akhir di dalam suatu pengimplementasian software akuntansi akan meningkatkan niat penggunaan software yang tercermin lewat meningkatnya nilai peng-gunaan sistem, sehingga pada akhirnya memberikan kontribusi terhadap keberhasilan implementasi dari software akuntansi tersebut. Hasil ini konsisten dengan Penelitian Kurniawan dan Cahyo (2010), Sumiyana dan Angelina (2010), Imam (2009) yang menyatakan bahwa kepuasan pengguna akhir berpengaruh positif terhadap penggunaan sistem. Hasil $\mathrm{H}_{5}$ menunjukkan bahwa kualitas informasi tidak berpengaruh positif terhadap penggunaan sistem. Jika kualitas informasi pada suatu software akuntansi sangat bagus maka akan semakin bisa menarik pengguna untuk menggunakan sistem tersebut namun pada penelitian ini kualitas informasi tidak cukup menarik minat pengguna system informasi. Hasil ini berbeda dengan penelitian Kurniawan dan Cahyo (2010), Widananto (2008), Kartana (2008) 
yang menyatakan bahwa kualitas informasi berpengaruh positif terhadap penggunaan sistem.

Hipotesisi enam menyatakan bahwa persepsi kualitas system tidak berpengaruh positif terhadap penggunaan sistem. Persepsi kualitas sistem terkait dengan para pengguna akhir yaitu sehubungan dengan persepsi mereka tentang sistem dan juga kualitasnya dari suatu software akuntansi tersebut. Jika pengguna memiliki persepsi yang baik terhadap suatu software akuntansi maka mereka akan menggunakan software akuntansi tersebut, dan disinilah yang dimaksud dengan penggunaan sistem, mereka akan percaya dan yakin bahwa dengan menggunakan software tersebut bisa membantu mereka dalam menyelesaikan tugas-tugas mereka dan akan meningkatkan kinerja mereka.

Jika mereka merasa terbantu dan merasa bahwa kinerjanya semakin meningkat dengan adanya sistem tersebut maka para pengguna pasti akan sering menggunakan software akuntansi tersebut. Pengujian ini tidak konsisten dengan hasil Kurniawan dan Cahyo (2010), Septi (2011) yang menyimpulkan bahwa persepsi kualitas sistem mempunyai pengaruh positif terhadap penggunaan system karena masih terdapat factor lain yang memepengaruhi hal tersebut.

Pengujian $\mathrm{H}_{7}$ menunjukan bahwa kepuasan pengguna akhir tidak berpengaruh positif terhadap dampak individual. Kepuasan pengguna akhir di dalam suatu pengimplementasian software akuntansi tidak selalu meningkatkan penggunaan software akun-tansi. Semakin sering pengguna memakai sistem informasi, biasanya diikuti oleh semakin banyak tingkat pembelajaran (degree of learning) yang didapat mengenai sistem informasi. Peningkatan derajat pembelajaran ini merupakan salah satu indicator bahwa terdapat pengaruh keberadaan sistem terhadap dampak individual (individual impact). Dampak individual yang dimaksud adalah dampak dari software akuntansi terhadap perilaku dan kinerja penggunanya. Hasil hipotesisi ini berbeda dengan penelitian Kurniawan dan Cahyo (2010), Imam (2009), Kartana (2008) yang menyimpulkan bahwa ada pengaruh positif kepuasan pengguna akhir terhadap dampak individual.

Pengujian $\mathrm{H}_{8}$ berhasil membuktikan penggunaan sistem berpengaruh positif terhadap dampak individu. Penerapan sistem informasi yang baru akan berdampak pada reaksi yang ditunjukkan oleh perilaku individu dalam organisasi. Reaksi ini dapat berupa munculnya motivasi baru untuk bersaing dan meningkatkan kinerja. Secara positif keberadaan sistem informasi baru akan menjadi rangsangan (stimulus) dan tantangan bagi individu dalam organisasi untuk bekerja lebih baik. Hasil ini konsisten dengan penelitian Kurniawan dan Cahyo (2010), Imam (2009) yang menyimpulkan bahwa penggunaan sistem mempunyai pengaruh positif terhadap dampak individual.

\section{SIMPULAN}

Berdasarkan hasil analisis yang telah dilakukan dapat diambil kesimpulan bahwa kualitas sistem berpengaruh positif terhadap persepsi kualitas sistem. Persepsi kualitas sistem tidak berpengaruh positif terhadap kepuasan pengguna akhir. Kualitas informasi berpengaruh positif terhadap kepuasan pengguna akhir. Kepuasan pengguna akhir berpengaruh positif terhadap penggunaan sistem. Kualitas informasi tidak berpengaruh positif terhadap penggunaan sistem. Persepsi kualitas sistem tidak berpengaruh positif terhadap penggunaan sistem. Kepuasan pengguna akhir tidak berpengaruh positif terhadap dampak individual. Penggunaan sistem memiliki pengaruh positif terhadap dampak individu.

Berdasarkan kesimpulan dan analsis sebelumnya maka penulis memberikan saran pihak pengelola LKM PNPM UPK dalam mengambil keputusan 
untuk mengadopsi software hendaknya melibatkan pengguna akhir yang berhadapan langsung dengan operasi harian. Indikator-indikator (variabel manifest) yang berdampak bagi kinerja individu pengguna akhir sebagaimana telah diuji dalam penelitian ini seyogyanya menjadi bahan pertimbangan bagi pihak manajemen guna meminimalkan kegagalan adopsi software akuntansi tertentu. Peneliti yang akan datang hendaknya memperluas wilayah survei pada seluruh kabupaten dan kota di Indonesia. Untuk penelitian selanjutnya disarankan untuk memodifikasi model yang diajukan agar kriteria goodness of fit yang didapat akan terpenuhi kriteria yang baik.

\section{DAFTAR PUSTAKA}

Cahyo, A. dan F.X Tjakrawala K. 2010. Adaptasi Model Delone dan McLean yang Dimodifikasi Guna Menguji Keberhasilan Implementasi Software Akuntansi Bagi Individu Pengguna: Studi empiris Pada Perusahaan Dalam Industri Barang Konsumsi yang Tetrdafatar di BEI. Paper dipresentasikan pada acara Simposium Nasional Akuntansi XIII, Purwokerto.

Chin, W. W. 1998. The Partial Least Squares Approach To Structural Equation Modeling. Modern methods for business research, 295 (2), 295-336.

Chin, W. W., dan P. A. Todd. 1995. On The Use, Usefulness, Dan Ease Of Use Of Structural Equation Modeling In MIS Research: A Note Of Caution. MIS quarterly, 237-246.

Davis, F. D., R. P. Bagozzi, dan P. R. Warshaw. 1989. User Acceptance Of Computer Technology: A Comparison Of Two Theoretical Models. Management science, 35 (8), 982-1003.

DeLone, W.H. dan McLean. 1992. Information System Success: The Quest for the Dependent Variable. Infomation System Research, 3, 115-132

Dita, E.S. 2011. Adaptasi Model Delone dan McLean yang dimodifikasi Guna Mrnguji Keberhasilan Implementasi Aplikasi Operasional Bank Bagi Individu pengguna : Studi Empiris pada Bank Umum di Kota Semarang. Skripsi, Universitas Diponegoro.

Edberg, D. T. dan B. J. Bowman. 1996. User-Developed Applications: An Empirical Study Of Application Quality Dan Developer Productivity. Journal of Management Information Systems, 167-185.

Guimaraes, T., M. Igbaria dan M. Lu. 1992 The Determinants Of DSS Success: An Integrated Model. Decision Sciences, 23 (2), 409-427.

Guimaraes, T., D. S. Staples, dan J. D. Mckeen. 2003. Empirically Testing Some Main User-Related Factors For Systems Development Quality. The Quality Management Journal, 10 (4), 39-54.

Imam, M. 2009. Uji Empiris Model Kesuksesan Sistem Informasi Keuangan Daerah (SIKD) dalam Peningkatan Transparasi dan Akuntabilitas Keuangan Daerah. Paper dipresentasikan pada acara Simposium Nasional Akuntansi XII, Palembang.

Istianingsih dan S. Wijanto. 2008. Analisis Keberhasilan Penggunaan
Perangkat Lunak Akuntansi Ditinjau Dari Persepsi Pemakai (Studi Implementasi Model Keberhasilan Sistem Informasi). Jurnal Akuntansi dan Keuangan Indonesia, 5 (1), 50-76.

Istianingsih dan S. Wijanto. 2008. Pengaruh Kualitas Sistem Informasi, Perceived Usefulness, dan Kualitas Informasi Terhadap Kepuasan Pengguna Akhir Software Akuntansi. Paper dipresentasikan pada acara Simposium Nasional Akuntansi XI, Pontianak.

Istianingsih dan W. Utami. 2009. Pengaruh Kepuasan Pengguna Sistem Informasi terhadap Kinerja Individu (Studi Empiris Pada pengguna Paket Progam Aplikasi Sistem Informasi Akuntansi di Indonesia). Paper dipresentasikan pada acara Simposium Nasional Akuntansi XII, Palembang.

Jogiyanto H.M. 2000. Sistem Informasi Akuntansi Berbasis Komputer: Konsep Dasar dan Komponen, BPFE Yogyakarta.

Kartana. 2008. Pengujian Kesuksesan pengembangan Sistem Informasi Manajemen Daerah di Pemerintah Kota Yogyakarta. Tesis, Universitas Gadjah Mada.

Latan, H. dan Ghozali, I. 2012. Partial Least Squares Konsep, Teknik dan Aplikasi Menggunakan Program SmartPLS 2.0 M3. Semarang: Badan Penerbit Universitas Diponegoro.

Leavitt, H. J. 1965. Applied Organizational Change in Industry, I JG March (ed.) Handbook of Organizations. Chicago: Rdan McNally.

Livary, J. 2005. An Empirical Test of The DeLone-McLean Model of Information System Success. Dataabase for Advance in Information System (DFA), 36, 145-150.

McGill, T., V. Hobbs dan J. Klobas. 2003. Users Developed Application dan Information System Success: A Test of Delone dan McLean's Model. Information Resource Management Journal, 16 (1), 24-45.

McGill, T. dan J. E. Klobas. 2009. A Task-Technology Fit View Of Learning Management System Impact. Computers \& Education 52 (2), 496-508.

Melone, Nancy Paule. 1990. A Theoretical Assessment Of The UserSatisfaction Construct In Information Systems Research. Management science, 36 (1), 76-91.

Radityo, D dan Zulaikha. 2007. Pengujian Model DeLone dan McLean Dalam Pengembangan Sistem Informasi Manajemen (Kajian Sebuah Kasus). Paper dipresentasikan pada acara Simposium Nasional Akuntansi X Makassar.

Rivard, S., G. Poirier, L. Raymond, dan F. Bergeron. 1997. Development Of A Measure To Assess The Quality Of User-Developed Applications. ACM SIGMIS Database, 28 (3) , 44-58.

Roldán, J. L., dan A. L. Millán. 2000. Analysis Of The Information Systems Success Dimensions Interdependence: An Adaptation Of The Delone \& Mclean's Model In The Spanish EIS Field. Paper was Presented at BITWorld Conference.

Seddon, Peter B. 1987. Respesificaation dan Extension of the DeLone dan McLean Model of IS Success. Information System Research, 8 3-19.

Sumiyana dan Angelina. 2006. Model Komitmen Multidimensional atas Pilihan Adopsi Sistem dan Perilaku Pemraktikan (Studi Empiris di Jogjakarta). Paper dipresentasikan pada acara Simposium Nasional Akuntansi IX, Padang.

Wahju, W. 2008. Analisis Penggunaan Sistem Informasi Direktorat Jenderal Pajak di KPP Pratama dengan Menggunakan Model Kesuksesan DeLone McLean. Skripsi, Universitas Gadjah Mada Widjayanto, N. 2001. Sistem Informasi Akuntansi. Jakarta: Erlangga. Yoon, Y, T. Guimaraes, dan Q. O'Neal. 1995. Exploring The Factors Associated With Expert Systems Success. MIS quarterly, 83-106. 